\title{
Review Nanomaterial Sebagai Sensor Melamin dan Zat Aditif lainnya Secara Kolorimetri
}

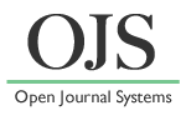

\author{
Wangi Pusva K.*, Edwin Saputra, Rima Mayesmy H., M. Lutfi Firdaus \\ Program Studi Pendidikan Kimia, Universitas Bengkulu \\ *Email: wangipusvakartini@gmail.com
}

DOI: https://doi.org/10.33369/pendipa.4.3.98-115

\begin{abstract}
[The use of nanomaterials as colorimetric sensors for melamine and other additives] Humans need nutrients for their survival. One of the nutrients needed by humans is protein. Protein can be obtained through food or beverage products. Products that contain a lot of protein, one of which is found in milk. Howecer, milk often contains additives that are harmful to health, such as melamine. The illegal addition of melamine to milk is intended to increase the high nitrogen content (66\% by mass) so that when the milk is analyzed as if it has a high protein content. In this review article, a literature analysis was carried out on how to detect levels of melamine and other synthetic substances. It was found that the detection could be done by the colorimetric method using nanomaterials (AuNps and AgNps). The fiber-optic-based biosensing system uses local surface plasmon resonance from AuNPs and AgNPs for melamine colorimetric detection. The experimental results show a good linear relationship between the difference in absorbance values at a wavelength of $520 \mathrm{~nm}$ of AuNPs and the concentration of melamine in liquid milk ranging from $0.1 \mu M$ to $0.9 \mu M$ and within the detection limit of $33 n M$.
\end{abstract}

Keywords: Nanomaterials, gold and silver nanoparticles, melamine, colorimetry, spectroscopy.

\begin{abstract}
ABSTRAK
Manusia membutuhkan nutrisi untuk kelangsungan hidupnya. Salah satu nutrisi yang dibutuhkan oleh manusia adalah protein. Protein dapat diperoleh melalui produk makanan atau minuman. Produk yang memiliki kandungan protein yang cukup tinggi, salah satunya terdapat pada susu. Akan tetapi, susu seringkali mengandung zat aditif yang berbahaya bagi Kesehatan, seperti melamin. Penambahan melamin secara ilegal pada susu ditujukan untuk meningkatkan kadar nitrogen yang tinggi (66\% massa) sehingga pada saat susu diperiksa seolah-olah susu tersebut mempunyai kandungan protein yang tinggi. Dalam artikel review ini, kami melakukan studi literatur bagaimana cara mendeteksi kadar melamin dan zat sintesis serta aditif lainnya di dalam makanan dan minuman. Hasil yang diperoleh yaitu nanopartikel dapat menganalisis kandungan melamin dengan metode kolorimetri menggunkan nanomaterial (AuNPs dan AgNPs). Sistem biosensing berbasis serat optik menggunakan resonansi plasmon permukaan lokal dari AuNPs dan AgNPs untuk deteksi kolorimetri melamin. Hasil percobaan dari literatur yang didapat menunjukkan hubungan linier yang baik antara perbedaan nilai absorbansi pada panjang gelombang 520 $\mathrm{nm}$ dari AuNPs dengan konsentrasi melamin dalam susu cair berkisar antara $0,1 \mu \mathrm{M}$ sampai $0,9 \mu \mathrm{M}$ dan dalam batas deteksi $33 \mathrm{nM}$.
\end{abstract}

Kata kunci: Nanomaterial, nanopartikel emas dan perak, melamin, kolorimetri, spektroskopi. 


\section{PENDAHULUAN}

Manusia membutuhkan nutrisi untuk kelangsungan hidupnya. Salah satu nutrisi yang dibutuhkan oleh manusia adalah protein. Protein dapat diperoleh melalui produk makanan atau minuman. Produk yang memiliki kandungan protein yang cukup banyak salah satunya terdapat pada susu. Akhir-akhir ini ditemukan kasus bahwa pada susu mengandung zat aditif yang berbahaya bagi kesehatan. Zat aditif tersebut adalah melamin. Penambahan melamin secara ilegal pada susu ditujukan untuk meningkatkan kadar nitrogen yang tinggi (66\% massa) sehingga pada saat susu diperiksa seolah-olah susu tersebut mempunyai kandungan protein yang tinggi, karena secara umum kandungan protein ditetapkan menggunakan metode Kjeldahl dengan cara menentukan kandungan nitrogennya (Sun et al.,2010).

Melamin merupakan suatu senyawa kimia organik dalam bentuk kristal, mengandung banyak nitrogen dan biasa digunakan dalam produk nonpangan (MenKes, 2012). Melamin banyak digunakan untuk produksi alat plastik seperti pada peralatan makan (Vail et al., 2007). Selain itu, melamin juga digunakan untuk produksi bahan adesif, laminasi, cat, industri tekstil, lapisan kertas, dan campuran fertilizer (Liu et al., 2012).

Adanya melamin dalam produk pangan dapat menyebabkan gagal ginjal. Kasus tersebut terjadi di Amerika Serikat, Kanada dan Afrika dimana adanya melamin pada produk makanan yang diimpor dari Cina menyebabkan kematian pada kucing dan anjing akibat gagal ginjal (WHO, 2008). Selain itu, di Hongkong terjadi kasus meninggalnya anak-anak akibat ditemukannya melamin pada susu (Du, 2008 dalam Octaviana dkk.). Hal ini membuktikan bahwa adanya melamin pada produk pangan memberikan dampak yang buruk bagi kesehatan. Maka, salah satu cara untuk menghindari dampak yang buruk dari melamin, dapat dilakukan dengan menganalisis kadar melamin dalam susu. Beberapa metode seperti elektroforesis kapiler, Gas Chromatography-Mass Spectrometry (GC-MS), Liquid Chromatography-Mass Spectrometry (LCMS), dan High Performance Liquid Chromatography (HPLC) telah dikembangkan dan digunakan untuk menganalisis kandungan melamin.
Meskipun metode tersebut memiliki nilai metode validasi yang tinggi, namun membutuhkan waktu operasional yang lama, dan instrumentasi yang relatif mahal. Dengan demikian, diperlukan pengembangan metode analisis yang sederhana, cepat dan sensitif untuk sebagai sensor analisis melamin dan zat aditif lainnya.

Selama satu dekade terakhir ini, penelitian di bidang nanopartikel menjadi topik yang sangat populer. Hal ini disebabkan oleh manfaat dan dampaknya yang sangat luas dalam kehidupan manusia. Manfaat dan aplikasi nanopartikel saat ini telah berkembang di berbagai bidang, antara lain di bidang lingkungan, biomedis, kesehatan, pertanian dan pangan, serta energi (Tzusuki, 2009).

Penelitian yang menggunakan sensor untuk mendeteksi melamin mulai banyak dikembangkan. Nanopartikel emas (AuNp) yang memiliki serapan pada panjang gelombang Visible dapat digunakan sebagai sensor colorimetric ideal untuk mendeteksi melamin. Penggunaan AuNp sebagai sensor melamin dapat dilakukan melalui modifikasi atau secara langsung. AuNp telah digunakan langsung untuk mendeteksi melamin dimana gugus $-\mathrm{NH}_{2}$ yang dimiliki melamin akan berinteraksi dengan AuNp sebagai ligan dan membentuk kompleks yang stabil (Li, Li, 2010). Akan tetapi, AuNp tidak hanya berinteraksi dengan gugus $-\mathrm{NH}_{2}$ milik melamin saja, tetapi juga dengan gugus $-\mathrm{NH}_{2}$ dalam susu yang mengandung protein-protein. Oleh karena itu, perlu dilakukan denaturasi protein terlebih dahulu pada sampel susu yang akan digunakan dengan asam trikloroasetat (Li, Li, 2010).

Selain nanopartikel emas yang dapat digunakan untk mendeteksi keberadaan melamin, nanomaterial lain yang bisa digunakan adalah nanopertikel perak. Nanopartikel perak (AgNPs) merupakan salah satu nanopartikel logam yangdapat digunakan untuk mendeteksi keberadaan melamin. Beberapa penelitian menggunakan AgNPs yang dimodifikasi dengan senyawa organik untuk mendeteksi melamin, diantaranya $p$-nitroanilin dengan limit deteksi 7,9 x 10 (Han dan Li, 2010), dopamin-AgNPs dengan limit deteksi 7,9 x 10-8 mL (Ma dkk., 2011), sitrat-AgNPs dengan limit deteksi 8,0 x 10 (Wang dkk., 2012), sitrat-AgNPs dengan 
limit deteksi 2,3 x 10 -6 mL-1 (Ping, dkk., 2012), asiklodextrin-AgNPs dengan limit deteksi 3 x 103 mg/L (Ma dkk., 2013), asam kromotropikAgNPs dengan limit deteksi 3,6 x 10 (Song dkk., 2014).

Nanopartikel bisa dibuat dengan cara sintesis dngan menggunakan bahan kumia namun hal tersebut dapat menyebabkan produksi limbah bahan kimia dan berbahaya untuk lingkungan. Sehingga pembuatan nanopartikel emas dapat dilakukn dengan memanfaatkan tanaman sebagai agen pereduksi yaitu dengan metode biosintesis. Oleh karena itu dalam penelitian ini digunakan AuNp dari ekstrak kulit buah naga yang dimodifikasi sebagai sensor melamin dan zat aditif lain. AuNp yang digunakan dibuat dari pereduksi dari ekstrak kulit buah naga untuk mendapatkan ukuran nanopartikel yang kecil dari larutan $\mathrm{HAuCl}_{4}$ sebagai sumber $\mathrm{Au}^{3+}$ (Manna, A, 2003). Untuk meningkatkan keselektifan AuNp dimodifikasi dengan Polivinilalkohol (PVA) sebagai agen stabilisator sehingga dapat dimanfaatkan sebagai detektor dan indikator pada kolorimetri (Caro et al., 2010). Metode kolorimetri digunakan untuk mengetahui adanya reaksi yang terjadi antara NPE dan sampel maupun NPP dan sampel.

Dalam ulasan ini, berdasarkan data-data yang diperoleh dari data sekunder kami membahas nanopartikel emas dan perak sebagai basis sensor, dikarenakan penggunaan AuNps dan AgNps menyediakan hasil relatif cepat, akurat dan murah dalam mendeteksi keberadaan melamin dalam produk makanan Beberapa penelitian menggunakan AuNPs dan AgNPs sebagai sensor melamin telah dilakukan dengan hasil yang memuaskan. Di samping itu beberapa penelitian lain menunjukkan bahwa AuNPs dan AgNPs selain mendeteksi melamin juga dapat menganalisis polimer sintetis lainnya seperti formaldehyde, clenbuterol salbutamol dan ractopamine. Namun selain faktor keefektifan, sensor berbasis nanopartikel ini hendaknya juga mementingkan efek bahayanya bagi lingkungan dengan memperhatikan cara sintesis nanopartikel tersebut. Green syhthesis nanopartikel merupakan pendekatan yang lebih ramah lingkungan untuk mendapatkan struktur nano dengan komposisi kimia yang lebih homogen. Studi mengenai biosintesis nanopartikel telah dilakukan dengan memanfaatkan ekstrak kulit buah naga untuk mensintesis nanopartikel emas dan perak. Oleh karena itu tinjauan mengenai sensor berbasis nanomaterial diperlukan untuk mengarahkan desain-desain baru untuk mendeteksi melamin dan zat aditif lainnya yang sangat efisien.

Mengingat banyaknya bahaya yang ditimbulkan oleh beberapa polimer sintetis yang telah disebutkan di atas (melamin, clenbuterol, salbutamol, ractopamin dan formaldehyde), maka perlu adanya solusi untuk mengatasi hal itu. Salah satunya dengan menganalisis senyawa-senyawa tersebut serta konsentrasinya sebagai kontaminan di suatu produk pangan atau yang lain, sebagai upaya untuk meminimalisir bahaya yang dapat ditimbulkan. Beberapa metode yang akurat telah dilakukan seperti liquid chromatography/mass spectrometry (LC/MS), capillary electrophoresis (CE), ultrasound-assisted extractive electrospray ionisation (EESI), gas chromatography (GC), tandem mass spectrometry, andenzyme-linked immune sorbent assay (ELISA), namun metode-metode ini membutuhkan waktu operasional yang lama dan instrumen yang relatif mahal dan minim. Oleh karena itu diperlukan suatu metode lain yang sederhana, efektif, ekonomis serta akurat dalam analisis melamin dan polimer-polimer sintetis tersebut.

\section{Melamin Dan Polimer Sintetis Lainnya}

Melamin adalah suatu senyawa kimia organik yang paling umum didapat dalam bentuk kristal, mengandung banyak nitrogen dan biasa digunakan dalam produk non-pangan, yang apabila digunakan dalam pangan dapat membahayakan kesehatan manusia (MenKes, 2012).

Melamin berbahaya jika terminum, terhirup, atau terserap melalui kulit. Paparan secara kronis dapat menyebabkan efek kanker dan kerusakan sistem reproduksi. Para ahli Food Drug Administration (FDA) menjelaskan ketika melamin dan asam sianurat terserap dalam darah, maka akan terkonsentrasi dan berinteraksi di dalam saluran kelenjar ginjal saat pengisian urin, lalu akan mengkristal berupa kristal kuning dimana memblok dan merusak sel kelenjar ginjal yang akhirnya menutup saluran ginjal sehingga menyebabkan malfungsi ginjal (WHO, 2008).

Cemaran melamin telah diatur oleh Menteri Kesehatan RI Nomor 034 Tahun 2012 tentang Batas Maksimum Melamin Dalam Pangan, yaitu pada fomula bayi bentuk bubuk sebanyak 1 
$\mathrm{mg} / \mathrm{kg}$; pada formula bayi siap konsumsi $0,15 \mathrm{mg} / \mathrm{kg}$; pada pangan lain $2,5 \mathrm{mg} / \mathrm{kg}$. Pada WHO (2008) menetapkan batas limit melamin dalam susu formula bayi dapat ditoleransi sebesar $1 \mathrm{ppm}(1 \mathrm{mg} / \mathrm{kg})$.

Selain melamin, polimer sintetis lainnya yang disalahgunakan dalam produk pangan yaitu clenbuterol, salbutamol dan ractopamin. Penyalahgunaan ini dilakukan dengan alasan tertentu, salah satunya adalah Economically Motivated Adulteration (EMA) yaitu adanya penambahan adulterant dengan bertujuan meningkatkan nilai suatu produk pangan sehingga mendapatkan keuntungan ekonomi- Clenbuterol, salbutamol dan ractopamin termasuk dalam famili $\beta$ agonis. Ketiga struktur molekul senyawa ini disajikan pada gambar 1 Senyawa-senyawa ini umumnya digunakan sebagai agen bronkodilator, tokolitik, dan mukolitik yang mampu mengatasi penyakit paru dan asma. Namun karena memiliki kemampuan untuk meningkatkan laju pertumbuhan jaringan otot dan pengurangan lemak tubuh, hal inilah yang menyebabkan penyalahgunaan $\beta$-agonis pada pakan hewan penghasil daging. Mengkonsumsi produk daging yang mengandung $\beta$-agonis dapat menimbulkan bahaya kesehatan. Banyak literatur telah melaporkan kejadian keracunan dan potensi bahaya $\beta$-agonis. Efek samping akibat mengkonsumsi daging yang terkontaminasi senyawa-senyawa ini seperti, palpitasi jantung, takikardia, gugup, tremor otot, dan kebingungan bahkan menyebabkan penyakit kardiovaskular dan saraf pusat. Oleh karena itu, tidak ada $\beta$-agonis yang diizinkan untuk digunakan oleh manusia atau bahkan hewan di sebagian besar Negara, termasuk negaranegara Uni Eropa dan China.

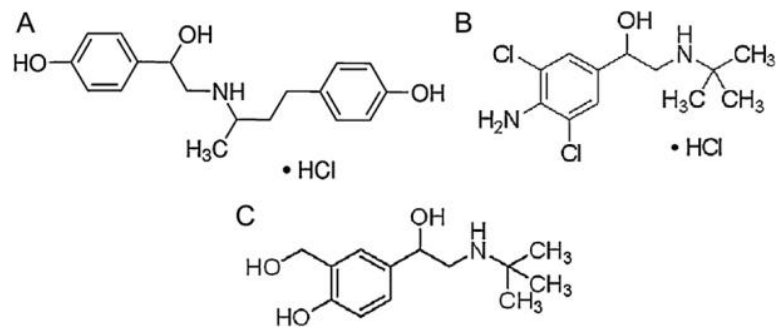

Gambar. 2. Struktur molekul (a) ractopamine, (b) clenbuterol dan (c) salbutamol (Zhang, H., et al, 2012).

Polimer sintetis lainnya yang juga berefek dapat mengganggu kesehatan manusia yaitu formaldehid yang merupakan gas tidak berwarna pada suhu kamar, memiliki bau yang menyengat dengan titik leleh berkisar dari $-118^{\circ} \mathrm{C}$ hingga -92 ${ }^{\circ} \mathrm{C}$ dan titik didih $-21{ }^{\circ} \mathrm{C}$ hingga $-19{ }^{\circ} \mathrm{C}$ (pada 101,3 $\mathrm{kPa}$ ) serta berat molekul 30,03, namun senyawa ini dianggap sebagai bahan kimia yang penting karena penggunaannya yang luas di berbagai bidang. Formaldehid $\left(\mathrm{CH}_{2} \mathrm{O}\right)$ tidak hanya ditemukan dalam konstruksi tetapi juga di berbagai industry, komponen dari banyak produk rumah tangga, bahkan disalahgunakan pada beberapa produk pangan, meskipun senyawa ini juga hadir secara alami di beberapa makanan serta dilepaskan dalam proses pembakaran, kebakaran hutan, dan knalpot mobil. Akibatnya, formaldehid ditemukan hampir setiap hari dari sebagian besar masyarakat. Bahan yang mengandung formaldehid dapat melepaskan gas formaldehida ke udara, oleh karena itu formaldehid biasanya hadir di udara baik di dalam dan luar ruangan pada tingkat rendah (40 ppb di dalam ruangan dan $15 \mathrm{ppb}$ di luar ruangan). Beberapa literatur telah menyebutkan efek samping (bahaya) dari formaldehid. Paparan akut akibat formaldehid dapat menyebabkan berbagai masalah kesehatan seperti iritasi pada berbagai bagian tubuh (mata, hidung, tenggorokan, dan kulit). Selain itu, paparan berkelanjutan dapat menyebabkan jenis kanker tertentu (misalnya, nasofaring) dan asma.

\section{Nanopartikel emas dan nanopartikel perak}

Partikel nano didefinisikan sebagai material berskala nanometer $\left(10^{-9} \mathrm{~m}\right)$. Sifat-sifat nanopartikel sangat berbeda dengan jumlah besar partikelnya. Sifat ini meliputi sifat elektrik, mekanik, magnetik maupun sifat optiknya. Material nano memiliki keunggulan yang dapat dimanfaatkan untuk aplikasi spesifiknya, misalnya saja dari sifat optiknya. Perbedaan ukuran setiap partikel terlihat jelas pada perbedaan warna yang dihasilkan, sesuai dengan teori Surface Plasmon Resonance (SPR). Hingga saat ini nanopartikel telah diaplikasikan dalam bidang elektronik, kedokteran, industri kimia, kosmetik dan lain-lain (Yi Sun, et al. 2006).

AuNp yang dimodifikasi dengan ligan dapat digunakan sebagai sensor ion logam yang spesifi seperti ligan dari Polivinilalkohol (PVA). Selain sebagai sensor logam, AuNp juga dapat digunakan sebagai sensor senyawa organik, misalnya 
melamin. AuNp dimodifikasi dengan Polivinilalkohol (PVA) agar lebih stabil dan selektif sebagai sensor melamin (Lu, Lehui, 2009).

Sedangkan sifat/karakteristik nanopartikel perak dipengaruhi oleh beberapa faktor diantaranya adalah ukuran, distribusi dan morfologi. Nanopartikel perak yang berukuran kecil akan memiliki luas permukaan yang lebih besar. Luas permukaan nanopartikel perak ini sangat menentukan sifat katalitik, sensor optik, dan antibakteri dari nanopartikel perak dimana semakin besar luas permukaan nanopartikel (semakin kecil ukuran partikel) maka kemampuan katalitik, sensor optik dan antibakteri nanopartikel juga akan meningkat (Song, 2009).

\section{METODE PENELITIAN}

\section{Pembuatan Ekstrak Kulit Buah Naga}

Kulit buah naga yang akan dipreparasi dipilih yang telah masak atau berwarna merah dan segar (Farida, 2009). Kemudian dicuci dan ditimbang sebanyak 20 gr. Selanjutnya dimasukkan ke dalam gelas kimia $150 \mathrm{~mL}$ dan ditambahkan dengan aquades sebanyak $100 \mathrm{~mL}$ dan dipanaskan selama 15 menit pada suhu $80^{\circ} \mathrm{C}$. Lalu, disaring dan ditutup dengan alumunium foil, untuk kemudian dilihat panjang gelombang.

Berikut pembuatan ekstrak kulit buah naga menurut Phongtongpasuk et.al (2016) yaitu diperoleh dengan mengekstrak kulit segar dengan air (rasio 1:20 berat /volum ) pada $100{ }^{\circ} \mathrm{C}$ selama 15 menit. Kemudian dilakukan filtrasi untuk mendapatkan ekstraknya. Filtrat dikumpulkan dan disimpan pada suhu $4{ }^{\circ} \mathrm{C}$ untuk digunakan lebih lanjut.

\section{Biosintesis Nanopartikel Emas}

Nanopartikel emas
Polivionilalkohol dibuat dengan $\begin{gathered}\text { termodifikasi } \\ \text { komposisi air }\end{gathered}$
rebusan kulit buah naga, HAuCl4 $1000 \mathrm{ppm}$ dan
ditambahkan Polivionilalkohol $0,1 \mathrm{mM}$ terbentuk
nanopartikel emas dengan rasio volume larutan $(1$
$: 10: 3) 10: 100: 30 \mathrm{~mL}$. Selanjutnya dikarakterisasi
dengan spektroskopi UV-Vis setelah 1 jam.

Nanopartikel emas termodifikasi Polivionilalkohol dibuat dengan komposisi air rebusan kulit buah naga, $\mathrm{HAuCl} 41000$ ppm dan ditambahkan Polivionilalkohol $0,1 \mathrm{mM}$ terbentuk nanopartikel emas dengan rasio volume larutan (1 dengan spektroskopi UV-Vis setelah 1 jam.

\section{Biosintesis Nanopartikel Perak}

Larutan diaduk selama 2-4 jam dengan pengaduk magnet pada suhu kamar. Nanopatikel perak dipisahkan dari campuran reaksi dengan sentrifugasi pada $12.000 \mathrm{rpm}$ selama 15 menit pada 4 ${ }^{\circ} \mathrm{C}$. Pelet itu tersebar kembali dalam deionisasi air dan disentrifugasi lagi pada kondisi yang sama seperti yang disebutkan di atas untuk mendapatkan kemurnian nanosilver. Kemudian, Liofilisasi dilakukan untuk mendapatkan serbuk nanopartikel perak. Pengaruh $\mathrm{pH}$ dipelajari dengan mengatur $\mathrm{pH}$ dari DPE menjadi 3,35, 4,35 dan 5,35 sebelum bereaksi dengan $\mathrm{AgNO}_{3}$ Campuran reaksi mengandung $220 \mathrm{ml}$ ekstrak buah naga dalam $110 \mathrm{ml}$ $10 \mathrm{mM}$ perak nitrat $\left(\mathrm{AgNO}_{3}\right)$.

\section{Surface Plasmon Resonance}

Salah satu aplikasi dari SPR nanopartikel yaitu penggunaanya sebagai sensor kolorimetrik, berdasarkan agregasi dan deagregasi AuNPs ketika target spesifik terdeteksi. Penurunan jarak antar partikel akan memicu terjadinya agregasi yang selanjutnya akan mengubah sifat optik dari nanopartikel tersebut. Terjadinya pergeseran merah dari plasmon akan menampakkan perubahan warna dari merah menjadi biru-keunguan yang dapat divisualisasi dengan mata telanjang (Zhou et al., 2012). Deteksi visual berdasarkan transisi warna sangat berguna untuk deteksi yang cepat di rumah sakit atau sarana kesehatan, dan dapat dilakukan oleh siapa saja, tanpa peralatan yang kompleks (He et al., 2011).

Metode kolorimetri merupakan metode yang berdasarkan penyerapan sinar tampak oleh suatu larutan berwarna. Dalam metode kolorimetri, sinyal target yang terjadi melalui perubahan warna dalam medium reaksi (Kim et al., 2001). Prinsip dari indikator kolorimetri berdasarkan pada sifat unik dari SPR (Surface Plasmon Resonance) suatu nanopartikel dan kemampuannya beragregasi (saling berikatan). SPR adalah suatu fenomena interaksi NPP untuk menyerap dan menyebarkan sinar dengan panjang gelombang yang spesifik (Singh et al., 2013).

\section{HASIL DAN PEMBAHASAN}

Mekanisme untuk pendeteksian kolorimetri melamin diilustrasikan dalam Gambar 1(a) . AuNP yang disintesis stabil dalam larutan air karena gaya tolakan antara anion sitrat pada permukaan AuNP 
yang mencegah AuNPs dari agregasi. Larutan AuNPs yang distabilkan dengan sitrat menunjukkan warna merah anggur. Ketika larutan melamin ditambahkan, tolakan elektrostatis antara AuNP disaring, yang mengarah pada agregasi AuNP. dan menyebabkan warna larutan menjadi biru. Alasannya adalah tiga gugus amina (-NH 2) molekul melamin akaberinteraksi dengan AuNPs dan disosiasi ion sitrat permukaan AuNP membuat mereka kehilangan kemampuan untuk menstabilkan AuNP.

Seperti yang ditunjukkan pada Gambar 1 (b) , spectrum serapan larutan AuNPs memiliki puncak serapan maksimum pada $520 \mathrm{~nm}$. Puncak serapan maksimum dari larutan berkurang bila melamin yang ditambahkan dengan konsentrasi 0,5 $\mu \mathrm{M}$. Selanjutnya, ketika $2 \mu$ Mmelamin ditambahkan ke dalam larutan AuNPs, puncak absorpsi baru pada sekitar 640 nm muncul. Dari sisipan Gambar 1 (b), terlihat jelas bahwa warna larutan AuNPs berubah dari merah menjadi biru. Spektrum serapan UVVisible dari AuNPs (Blank), AuNPs + $0,5 \mu$ Mmelamine, AuNPs $+2 \mu \mathrm{M}$ melamine dan AuNPs $+10 \mu$ Mmelamine ditunjukkan di gambar.
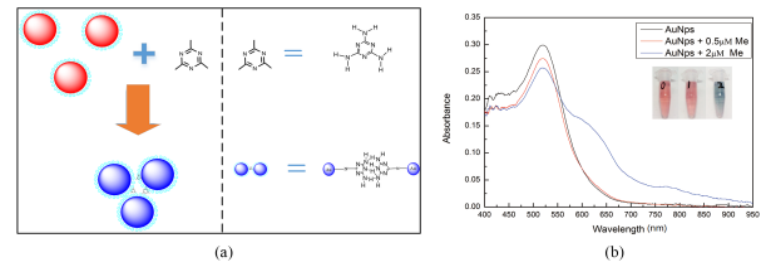

Gambar 1. (a) mekanisme deteksi kolorimetri melamin berdasarkan AuNP yang tidak dimodifikasi, (b) spectrum serapan dari AuNPs (blank), AuNPs + 0,5 $\mu$ melamin, dan AuNPs $+2 \mu$ melamin.

\section{Deteksi Melamin oleh Nanopartikel} deteksi melamin.

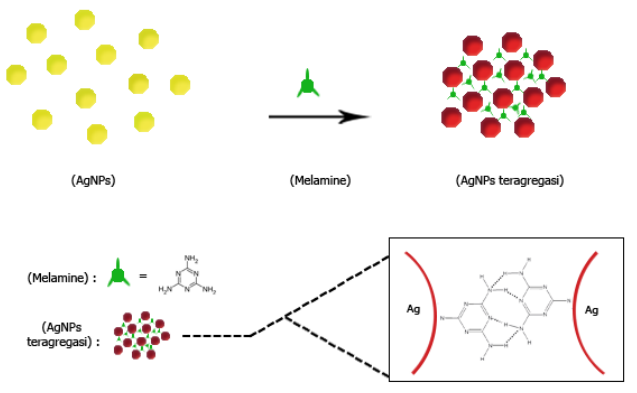

Skema 2.Mekanisme kolorimetri AuNPs untuk deteksi melamin.

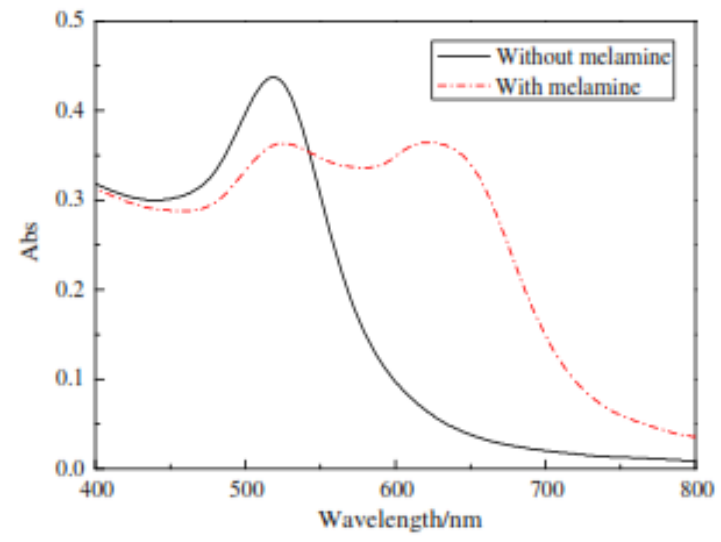

Gambar. 2. Spektrum absorpsi GNP dengan tidak adanya melamin (garis padat) dan dalam adanya melamin (garis putus-putus).

Pembentukan kurva standar 
Larutan melamin standar dengan konsentrasi berbeda, 0,05, 0,2, 0,4, 0,6 dan $0,9 \mu \mathrm{M}$, masingmasing ditambahkan ke dalam larutan AuNPs. Seperti yang bisa dilihat dari Gambar 3 , peningkatan konsentrasi melamin menyebabkan penurunan absorbansi larutan AuNPs pada panjang gelombang 520nm. Untuk mempelajari secara kuantitatif hubungan antara konsentrasi melamin dan absorbansi AuNPs, kami menetapkan perbedaan absorbansi $(\Delta)$ antara larutan AuNP dan larutan AuNP yang ditambahkan dengan melamin dengan konsentrasi berbeda sebagai variable absis dan konsentrasi melamin sebagai variabel ordinat. Kemudian kurva linier yang baik diperoleh dengan $\mathrm{R}$ square 0,99 antara konsentrasi dan absorbansi. Persamaan yang pas dari kurva linier adalah $\mathrm{y}=0,026 \mathrm{x}+0,01$ dan batas deteksi adalah $33 \mathrm{nM}$ sesuai rumus, dimana a adalah deviasi standar dan lereng adalah kemiringan garis lurus yang pas. Kurva kalibrasi linier yang diperoleh ditunjukkan pada gambar 3 .Hubungan linier antara rasio absorbansi dan konsentrasi melamin dalam kisaran 2,0-250,0 $\mu \mathrm{M}$, hubungan linier antara absorbansi dan konsentrasi melamin dalam kisaran $0,4-4 \mu \mathrm{M}$, korelasi linier antara absorbansi dan konsentrasi melamin mulai dari $0,9 \mu \mathrm{M}$ hingga $3,1 \mu \mathrm{M}$ telah divalidasi. Oleh karena itu, dapat dilihat bahwa metode yang diusulkan tidak hanya memberikan deteksi kolorimetrik sensitif melamin pada konsentrasi rendah dalam kisaran 0 $0,9 \mu \mathrm{M}$ dengan koefisien korelasi (R2) 0,99 dan batas deteksi $33 \mathrm{nM}$, tetapi juga membuat memungkinkan instrumentasi spektroskopi yang kompak dan murah.

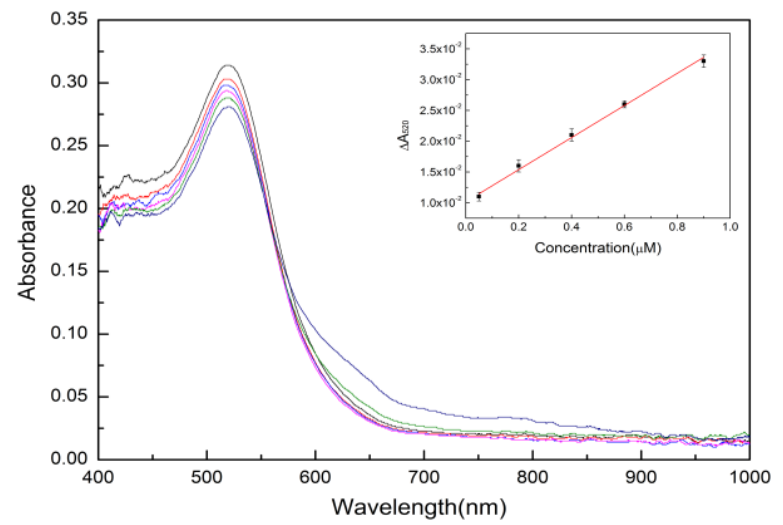

Gambar 3. Spektrum serapan UV-Visible AuNPs ditambahkan dengan konsentrasi melamin yang berbeda $(0,0,05,0,2,0,4,0,6$ dan $0,9 \mu \mathrm{M})$ dan kurva kalibrasi deteksi melamin.

\section{Zat aditif lainnya (Formaldehid)}

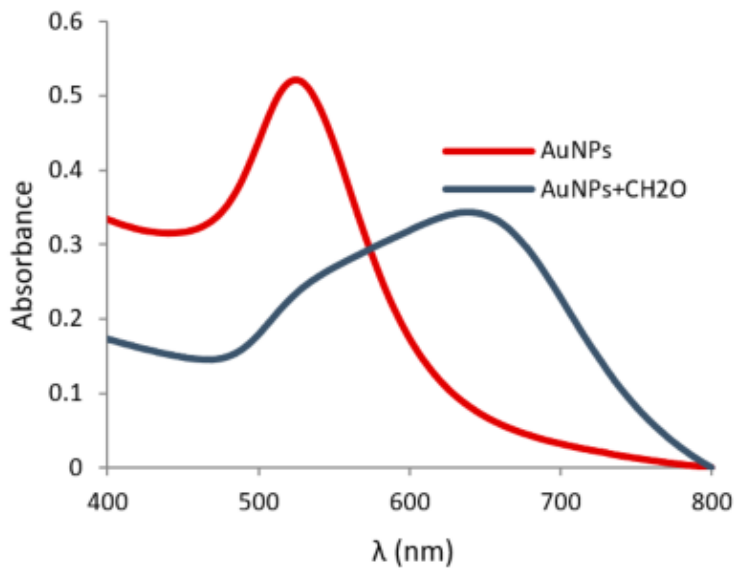

Gambar 4. Pergeseran panjang gelombang AuNPs

Nanopartikel emas (AuNP) telah disintesis dan digunakan untuk kolorimetri langsung deteksi formaldehida baik dalam media air dan fase gas. Proses deteksi didasarkan pad reaksi kondensasi antara formaldehida dan bagian resorcinol terminal dari dua bagian yang berbeda nanopartikel. Ini memicu agregasi dari partikel nano yang tersebar, menghasilkan batiokromik pergeseran pita SPR dalam spektrum UV-vis dan perubahan, dari merah ke biru, pada warna solusi, yang bisa diamati dengan mata. AuNP dapat mendeteksi formaldehida dalam larutan air dengan batas deteksi 0,5 ppm. juga mampu mendeteksi gas formaldehida yang dipancarkan dari serat dan papan partikel, memberikan respon yang lebih tinggi untuk papan partikel dengan kandungan formaldehida yang lebih tinggi. Nanopartikel emas fungsional AuNp telah disintesis dan digunakan secara langsung deteksi kolorimetri formaldehida baik dalam media air dan fase gas. Deteksi Proses ini didasarkan pada reaksi kondensasi antara formaldehida dan resorcinol terminal bagian dari dua nanopartikel yang berbeda. Ini memicu agregasi partikel nano yang tersebar, menghasilkan pergeseran batiokromik dari pita SPR dalam spektrum UV-vis dan perubahan, dari merah menjadi biru, dalam warna larutan, yang dapat diamati dengan mata. AuNP mampu mendeteksi formaldehida dalam larutan air dengan batas deteksi $0,5 \mathrm{ppm}$. mampu mendeteksi formaldehida gas yang dipancarkan dari serat dan papan partikel, memberikan respon yang lebih tinggi untuk papan partikel. 


\section{KESIMPULAN}

Hasil analisis menunjukkan bahwa nanopartikel dapat mendeteksi kandungan melamin di dalam sampel susu cair. Sistem biosensing berbasis serat optik menggunakan resonansi plasmon permukaan lokal berbasis serat optik dari AuNPs dan AgNPs berperan penting untuk deteksi kolorimetri melamin. Hasil percobaan menunjukkan hubungan linier yang baik antara perbedaan nilai absorbansi pada panjang gelombang $520 \mathrm{~nm}$ pada AuNPs dan konsentrasi melamin dalam susu cair yang berkisar antara $0,1 \mu \mathrm{M}$ sampai $0,9 \mu \mathrm{M}$ dan dalam batas deteksi $33 \mathrm{nM}$.

Dari hasil studi literatur, kami menemukan bahwa kolorimetri adalah metode sederhana dan cepat untuk uji melamin. Hal ini didasarkan bahwa melamin meghasilkan transisi warna koloid dari merah menjadi biru pada AuNPs. Seluruh analisis termasuk pretreatment sampel hanya berlangsung selama 12 menit denan batas deteksi adalah $0,4 \times 10^{-}$ $3 \mathrm{~g} / \mathrm{L}$. Deteksi melamin ini dapat diamati secara visual dan mudah digunakan.

\section{UCAPAN TERIMA KASIH}

Terima kasih kami ucapkan kepada semua pihak yang telah berpartisipasi dalam menyelesaikan artikel ilmiah narrative review ini. Artikel review ini dibuat sebagai salah satu luaran program kreativitas mahasiswa (PKM) yang didanai oleh Kemendikbud. Mudah-mudahn bisa bermanfaat bagi kemajuan ilmu pengetahuan.

\section{DAFTAR PUSTAKA}

Caro, C., Castillo, P. M., Klippstein, R., Pozo, D., and Zaderenko, A. P. 2010. Silver Nanoparticles: Sensing and Imaging Application. University of Seville- UPOJunta the andalucia-spain. Diakses 20 Januari 2018.

Chang K, Wang S, Zhang H, Guo Q, Hu X, Lin Z, et al. (2017) Colorimetric detection of melamine in milk by using gold nanoparticlesbased LSPR via optical fibers. PLoS ONE 12(5): e0177131. https://doi.org/10.1371/journal.pone.01771 31.

Chou, K. S. and Lu, Y. C. 2008. High-Concentration Nanoscale Silver Colloidal Solution and
Preparing Process Thereof. Patent Application Publication. US.2008/0064767 A1.

D. Divakaran, J.R. Lakkakula, M. Thakur, M. Kumar Kumawat, R. Srivastava. 2018. Dragon fruit extract capped gold nanoparticles: Synthesis and their differential cytotoxicity effect on breast cancer cells, Materials Letters doi: https://doi.org/10.1016/j.matlet.2018.10.15 $\underline{6}$

Han, C.P. dan Li, H.B. 2010. Visual Detection of Melamine in Infant Formula at $0.1 \mathrm{ppm}$ Level Based on Silver Nanoparticles. Analyst.135: 583-588.

Li, Li; Li, Baoxin; Chang, Di; dan Mao, Lihui. 2010. Visual detection of melamine in raw milk using gold nanoparticles as colorimetric probe. Food Chemistry Vol.122, issue 3, 1 October 2010, Pages 895-900.China: ScienceDirect

Liu, Y., Todd, E. E. D., Zhang, Q., Shi, J., and Liu, X. 2012. Review: Recent Developments in The Detection of Melamine. Journal of Zhejiang University Science B (Biomedicine \& Biotechnology. Vol. 13, No. 7. Hal: 525532.

Ma, P., Liang, F., Sun, Y., Jin, Y., Chen, Y., Wang, X., Zhang, H., Gao, D., Song, D. 2013. Rapid determination of melamine in milk and milk powder by surface-enhanced Raman spectroscopy and using cyclodextrindecorated silver nanoparticles. Microchim. Acta. 180:1173-1180

Ma, Y.R., Niu, H.Y., Zhang, X.L. dan Cai, Y.Q. 2011. One-step Synthesis of Silver/dopamine Nanoparticles and Visual Detection of Melamine in Raw Milk. Analyst. 136: 41924196.

Ping, H., Zhang, M.W., Li, H.K., Li, S.G., Chen, Q.S., Sun, C.Y. dan Zhang, T.H. 2012. Visual Detection of Melamine in Raw Milk by Label-free Silver Nanoparticles. Food Control. 23: 191-197

Octaviana, Y., Zakir, M., dan Raya, I. Sintesis Nanopartikel Emas dengan Bioreduktor Ekstrak Daun Belimbing Wuluh (Averrhoa bilimbi L.) yang Dimodifikasi 2,4,6-Tritiol1,3,5-Triazin untuk Sensor Melamin. Jurnal.

Singh, A., Jha, S., Srivastava, G., Sarkar, P., and Gogoi, P. 2013. Silver Nanoparticles as 
Fluorescent Probes: New Approach For Bioimaging. International Journal of Scientific \& Technology Research. Vol. 2, No. 11. Hal: 153-157

Song, J.Y and Kim, B.S. 2009. Rapid Biological Synthesis of Silver Nanoparticles Using Plant Leaf Extracts. Bioprocess and Biosystem Engineering. 32(1): 79-84.

Song, J., Wu, F., Wan, Y. dan Ma, L.H. 2014.

Visual Test for Melamine using Silver Nanoparticles Modified with Chromotropic Acid. Microchim. Acta. 181: 1267-1274.

Sun, F., Ma, W., Xu, L., Zhu, Y., Liu, L., Peng, C., Wang, L., Kuang, H., and Xu, C. 2010. Analytical Methods and Recent Developments in The Detection of Melamine. Trends in Analytical Chemistry. Vol. 29, No. 11. pp: 1239-1249.
Wang, Y., Yang, F., and Yang, X. 2010. Colorimetric Detection of Mercury (II) Ion Using Unmodified Silver Nanoparticles and Mercury-Spesific Oligonucleotides. Applied Materials \& Interfaces. Vol. 2, No. 2. Pp: 339-342.

WHO. 2008. Toxicological and Health Aspects of Melamine and Cyanuric Acid. Canada: World Health Organization. 